\title{
Effect of Feed Supplementation with Clostridium butyricum, Alone or in Combination with Carob Meal or Citrus Pulp, on Digestive and Metabolic Status of Piglets
}

\author{
Marina López ${ }^{1}$, Josefa Madrid ${ }^{1, *} \mathbb{1}$, Fuensanta Hernández ${ }^{1} \oplus$, Martín Antonio Ros ${ }^{2}$, Juan Carlos Segura ${ }^{2}$, \\ Miguel José López ${ }^{1}$, Francisco José Pallarés ${ }^{3}$, Cristian Jesús Sánchez ${ }^{1} \mathbb{D}$ and Silvia Martínez-Miró ${ }^{1} \mathbb{D}$ \\ 1 Department of Animal Production, Faculty of Veterinary Science, Regional Campus of International \\ Excellence "Mare Nostrum", University of Murcia, 30100 Murcia, Spain; marina.lopez9@um.es (M.L.); \\ nutri@um.es (F.H.); mjlopeza@um.es (M.J.L.); cristianjesus.sanchez@um.es (C.J.S.); silviamm@um.es (S.M.-M.) \\ 2 Agrarian Transformation Society, Number 2439, La Hoya, 30816 Lorca, Spain; mros@alia.es (M.A.R.); \\ jcsegura@alia.es (J.C.S.) \\ 3 Department of Anatomy and Comparative Pathology and Toxicology, Faculty of Veterinary Medicine, \\ Agrifood Campus of International Excellence-ceiA3, University of Córdoba, 14014 Córdoba, Spain; \\ fpallares@uco.es \\ * Correspondence: alimen@um.es; Tel.: +34-868-884-750
}

\section{check for}

updates

Citation: López, M.; Madrid, J.; Hernández, F.; Ros, M.A.; Segura, J.C.; López, M.J.; Pallarés, F.J.; Sánchez, C.J.; Martínez-Miró, S. Effect of Feed Supplementation with Clostridium butyricum, Alone or in Combination with Carob Meal or Citrus Pulp, on Digestive and Metabolic Status of Piglets. Animals 2021, 11, 2924. https://doi.org/10.3390/ani11102924

Academic Editor: Xiangfeng Kong

Received: 8 September 2021

Accepted: 6 October 2021

Published: 10 October 2021

Publisher's Note: MDPI stays neutral with regard to jurisdictional claims in published maps and institutional affiliations.

Copyright: (c) 2021 by the authors. Licensee MDPI, Basel, Switzerland. This article is an open access article distributed under the terms and conditions of the Creative Commons Attribution (CC BY) license (https:/ / creativecommons.org/licenses/by/ $4.0 /)$.
Simple Summary: During the intensive production of weaned piglets, frequent digestive disorders need to be avoided, as it is a critical phase; however, there are limitations to using antibiotics and $\mathrm{ZnO}$ at high levels. In this study, we investigate the inclusion of a probiotic (Clostridium butyricum) in combination with sources of fiber that might have a potential prebiotic effect, generating an optimal digestive status for weaned piglets. A trial is carried out using 30 post-weaning piglets for 27 days using five dietary treatments: a negative control, a positive control with high levels of $\mathrm{ZnO}$, and three dietary treatments supplemented with Clostridium butyricum (alone or in combination with carob meal or citrus pulp). Supplementation with this probiotic could improve the piglets' intestinal wellness status by increasing butyric acid, without being altered by the inclusion of carob meal or citrus pulp at $5 \%$, obtaining digestibility values comparable with those realized by the incorporation of high levels of $\mathrm{ZnO}$ in the diet. In addition, carob meal could decrease the concentration of serum interleukin-8 (a type of pro-inflammatory cytokine). However, a growth performance trial of piglets in commercial conditions needs to be developed to confirm these effects.

Abstract: This work studied the effects of the inclusion of Clostridium butyricum on feed, alone or with carob meal or citrus pulp, on the digestive and metabolic status of weaned piglets. A total of 30 male piglets (weaned at 21 days) is used. There are five dietary treatments: negative without $\mathrm{ZnO}$ at high doses $(\mathrm{C}-)$, a positive control supplemented with $\mathrm{ZnO}$ at $2500 \mathrm{ppm}$ of $\mathrm{Zn}(\mathrm{C}+)$, supplemented with Clostridium butyricum as a probiotic (PRO), and supplemented with probiotic and $5 \%$ carob meal (PROC) or 5\% citrus pulp (PROP). During the experiment (27 days), the piglets were periodically weighed and sampled for a serum biochemical, fecal microbiological, intestine histological, and digestive status analysis. The body weight, apparent ileal digestibility of dry matter (DM), and fecal microbiology were not affected by the treatments ( $p \geq 0.05)$. However, the apparent fecal digestibility of DM was lower for the $\mathrm{C}$ - treatment than for $\mathrm{C}+(p<0.05)$, and the total concentration of volatile fatty acids (VFAs) in feces with $\mathrm{C}+$ was lower than that for the PROC treatment $(p<0.05)$. The treatments with the probiotic had a higher molar proportion of butyric acid in feces than $\mathrm{C}_{+}$, and it was found that $\mathrm{C}$ - reached an intermediate value $(p<0.01)$. No general effects of diet were found on the histological measures performed on the jejunum and ileum, and in the serum biochemical analysis ( $p \geq 0.05$ ), only the concentration of interleukin- 8 was lower for the PROC treatment compared to the $\mathrm{C}-, \mathrm{C}+$, and PRO treatments $(p<0.05)$. In conclusion, the intestinal wellness of piglets could be improved with the supplementation of Clostridium butyricum by increasing butyric acid, and this effect was not altered with the inclusion of carob meal or citrus pulp. More studies under commercial conditions are needed, as the effects might be different in more challenging environmental circumstances. 
Keywords: piglets; Clostridium butyricum; carob meal; citrus pulp; digestive status; metabolic status

\section{Introduction}

The weaning of piglets is a critical period due to the dietary challenges for the pigs, and the social and environmental changes to which they are subjected [1]. Antimicrobial compounds have been widely used in feed for weaned piglets to improve performance and to prevent diarrhea [2]. However, concerns regarding the use of antibiotics have grown, due to the possible consequences that antibiotic resistance can have on human and animal health [3]. The European Union (EU) implemented a ban on using antibiotics as growth-promoting additives in non-medicated feeds for livestock from January 2006; they currently have a limited use even in medicated feeds. In addition, other products used to prevent digestive problems in piglets, based on zinc or copper, have been restricted due to the environmental problems that might be resulted [4]. Furthermore, feed supplementation with high levels of zinc oxide $(\mathrm{ZnO})$ has been related to the development of antibioticresistant microorganisms in piglets [5]. However, $\mathrm{ZnO}$ has been widely used at high levels ( $2500 \mathrm{ppm}$ of $\mathrm{Zn}$ ) as a strategy to prevent diarrhea in piglets, but the European legislation has set a target of zero $\mathrm{ZnO}$ usage in pharmacological doses in piglet feed by 2022 [6]. In this context, searching for alternative strategies to modulate the intestinal microorganisms of weaned piglets is a research goal. Among these alternatives are probiotics [7], which are harmless live microorganisms that balance intestinal microbiota for the benefit of the animal [8]. An example is the preparation Clostridium butyricum FERM-BP 2789, which was authorized as a zootechnical feed additive for weaned piglets (Regulation (EU) No 373/2011) [9]. This bacterium can produce butyric acid, which is an energetic substrate for intestinal epithelium cells and a regulator of intestinal $\mathrm{pH}$; consequently, it can preserve an optimal intestinal environment [10]. In piglets, some studies have shown that diet supplementation with Clostridium butyricum can improve the immune status, the structure of the intestinal mucosa, and the microbial profile of the intestine [11], resulting in an improvement of the feed conversion ratio [12]. This additive has also had positive effects during the weaning of piglets in combination with other probiotics $[13,14]$. However, there is little information on the use of Clostridium butyricum in combination with other substances with an additive or synergistic action that could improve the potential results of its use. In this way, the combination of probiotics with prebiotics is a strategy that is currently being studied [15]. A prebiotic is a food ingredient, totally or partially nondigestible, which can ferment in the digestive tract increasing the growth of the bacteria that could improve the health of the host [16]. Some fiber sources have shown prebiotic effects [17]. In post-weaning piglets, ingredients such as wheat bran and pea fibers have been able to modulate the intestinal microorganisms by stimulating the beneficial bacterial species, although others such as maize fiber and soyabean fiber did not show any positive effects [18].

Carob meal (originally from the fruit of Ceratonia siliqua) and citrus pulp are two fiber-rich by-products typical of the Mediterranean area having different fiber profile compositions [19], with carob meal having a higher neutral detergent fiber (NDF) and lignin content. In addition, carob pods are sweet with high levels of sucrose [20], giving it a more palatable characteristic, and carob is rich in tannins that confer astringent properties (preventing diarrhea), being a natural source of antioxidants [21]. Tannins (polyphenolic compounds), present in carob and its derivatives, are considered powerful antioxidants and anti-inflammatories, having bacteriostatic and antidiarrheal properties that could be of interest for piglet diets [22]. In addition, Andrés-Elias et al. [23] observed that the incorporation of carob in diets for piglets could affect the intestinal microbiota. Lizardo et al. [24] studied the incorporation of carob meal in the feed of weaned piglets and found that it did not affect the productive parameters, and the prevalence of post-weaning diarrhea dropped by $20-33 \%$ when carob meal was included at $3 \%$ and $6 \%$, respectively. 
Citrus by-products are rich in pectins (fermentable fiber) and, in addition, they have available biologically active compounds, such as polyphenols, carotenoids, and essential oils [25]. Furthermore, Hotchkiss et al. [26] concluded that pectic oligosaccharides from citrus fruits had prebiotic bifidogenic properties. In piglets, Pascoal et al. [27] indicated that a $9 \%$ citrus pulp inclusion decreased the occurrence of $E$. coli in the small intestines of piglets. Moreover, Collier et al. [28] showed that in newly weaned pigs challenged by E. coli $\mathrm{F} 18$, a $10 \%$ citrus pulp inclusion suppressed the ileal and cecal recovery of this pathogen. However, some studies on citrus pulp incorporation showed negative effects on nutrient utilization (at 4.5\% of inclusion) [29], and on incidences of diarrhea [30] or negative effects on performance [27] (at 9\% of inclusion); although, others authors did not find negative effects on performance when they included 7.5\% citrus pulp in the diets of weaned piglets [31]. Therefore, there is some controversy regarding the use of this ingredient in piglets.

Thus, beyond the traditional concept of using a prebiotic to enhance the action of a specific probiotic, the hypothesis of the present research is that the inclusion of a probiotic such as Clostridium butyricum, in combination with sources of fiber that could have a positive complementary effect, could generate a healthy digestive environment and improving the digestibility and physiological status of weaned piglets, but this effect could be different depending on the type of fiber ingredient. Therefore, the objective of the present work is to evaluate the effect of the inclusion of Clostridium butyricum, alone or with carob meal or citrus pulp, on the digestive and metabolic status of post-weaning piglets in optimal nursery conditions.

\section{Materials and Methods}

All experimental procedures performed in this work were in compliance with the protection of animals used for scientific purposes regulated by the European Union (2010/63/EU Directive) [32]. The administrative authorities and the Ethics Committee of the University of Murcia (Murcia, Spain) approved the protocol (code A13170502).

\subsection{Animal and Experimental Design}

The study was conducted for 27 days in the Animal Nutrition Experimental Unit at the veterinary farm of the University of Murcia (Guadalupe, Murcia, Spain) in optimal nursery conditions. A total of 30 piglets (non-castrated male, 100\% Large White breed) were weaned at 21 days old, individually identified, and weighed. The piglets had an average body weight (BW) of $5.06 \pm 0.64 \mathrm{~kg}$. They were housed in a controlled environment nursery, and were randomly allotted to one of the five dietary treatments, with six piglets per treatment. Each dietary treatment group was housed in a pen with a plastic slat floor and a space of $0.5 \mathrm{~m}^{2}$ per animal, equipped with feeders and nipple drinkers, offering ad libitum access to feed and water throughout the experiment.

The diets consisted of two control treatments, one negative without $\mathrm{ZnO}$ at high doses $(\mathrm{C}-)$, and one positive control $(\mathrm{C}+)$ consisting of a basal diet with $\mathrm{ZnO}$ added at a high level (2500 ppm of Zn), and another three experimental treatments, one only supplemented with Clostridium butyricum (Clostridium butyricum Miyairi 588 (FERM BP-2789), MIYA-GOLD ${ }^{\circledR}$ $\mathrm{S}$, Huvepharma ${ }^{\circledR}$, Antwerp, Belgium) to provide $2.5 \times 10^{8} \mathrm{CFU}$ per $\mathrm{kg}$ feed (PRO), and another two with the same probiotic plus $5 \%$ carob meal (PROC) or $5 \%$ citrus pulp (PROP). The commercial additive with Clostridium butyricum was included at $0.05 \%$, during the mixing of ingredients, to provide the feeds with this probiotic, at the established dose. The carob meal or citrus pulp were incorporated by substituting all of the sugar beet pulp and part of the barley of a basal diet, and carefully balancing the other minor ingredients until all diets were iso-energetic, iso-aminoacidic, and iso-neutral detergent fiber (iso-NDF). All experimental feeds were formulated to meet or exceed the requirements of piglets as indicated by the Spanish Foundation for the Development of Animal Nutrition (Fundación Española para el Desarrollo de la Nutrición Animal, FEDNA) [33]. In addition, 0.5\% $\mathrm{TiO}_{2}$ was included in all diets as an indigestible marker to determine the apparent fecal 
and ileal digestibility of the feeds (Table 1). The feeds were manufactured by Agrarian Transformation Society number 2439 (La Hoya, Spain) from the same ingredient batches. The diets were presented in mash form. In addition, the body weight (BW) of the piglets was controlled during the experiment on days 0,14 , and 26 .

Table 1. Ingredients and composition of experimental diets (as-fed basis).

\begin{tabular}{|c|c|c|c|c|c|}
\hline \multirow[t]{2}{*}{ Item } & \multicolumn{5}{|c|}{ Diets ${ }^{1}$} \\
\hline & $\mathrm{C}-$ & $\mathrm{C}+$ & PRO & PROC & PROP \\
\hline \multicolumn{6}{|l|}{ Ingredients, $\%$} \\
\hline Corn flakes & 16.00 & 16.00 & 16.00 & 16.00 & 16.00 \\
\hline Wheat flakes & 16.00 & 16.00 & 16.00 & 16.00 & 16.00 \\
\hline Dehulled barley flakes & 8.00 & 8.00 & 8.00 & 8.00 & 8.00 \\
\hline Corn & 9.08 & 9.08 & 9.08 & 9.57 & 8.77 \\
\hline Wheat & 9.90 & 9.90 & 9.90 & 8.00 & 8.00 \\
\hline Barley & 5.00 & 5.00 & 5.00 & 1.50 & 3.21 \\
\hline Soy-protein concentrate ${ }^{2}$ & 7.90 & 7.90 & 7.90 & 7.90 & 7.90 \\
\hline Soybean meal, $46 \%$ crude protein & 6.30 & 6.30 & 6.30 & 6.30 & 6.30 \\
\hline Porcine hydrolyzed protein ${ }^{3}$ & 2.19 & 2.19 & 2.19 & 2.87 & 2.64 \\
\hline Protein concentrate 4 & 2.00 & 2.00 & 2.00 & 2.00 & 2.00 \\
\hline Sweet whey (dried) & 5.00 & 5.00 & 5.00 & 5.00 & 5.00 \\
\hline Whey powder, $50 \%$ fat & 1.00 & 1.00 & 1.00 & 2.02 & 1.26 \\
\hline Dextrose monohydrate & 1.40 & 1.40 & 1.40 & 1.40 & 1.40 \\
\hline Titanium dioxide & 0.50 & 0.50 & 0.50 & 0.50 & 0.50 \\
\hline Soybean oil & 2.89 & 2.89 & 2.89 & 3.00 & 3.10 \\
\hline Sugar-beet pulp & 2.00 & 2.00 & 2.00 & & \\
\hline Carob meal & & & & 5.00 & \\
\hline Citrus pulp & & & & & 5.00 \\
\hline Probiotic ${ }^{5}$ & & & 0.05 & 0.05 & 0.05 \\
\hline Zinc oxide ${ }^{6}$ & & 0.31 & & & \\
\hline Vitamin-mineral premix ${ }^{7}$ & 0.40 & 0.40 & 0.40 & 0.40 & 0.40 \\
\hline Calcium carbonate & 1.00 & 1.00 & 1.00 & 1.00 & 1.00 \\
\hline Monocalcium phosphate & 0.80 & 0.80 & 0.80 & 0.88 & 0.87 \\
\hline Sodium chloride & 0.35 & 0.35 & 0.35 & 0.35 & 0.35 \\
\hline L-Lysine 50 (50\%) & 0.96 & 0.96 & 0.96 & 0.96 & 0.96 \\
\hline DL-Methionine (99\%) & 0.28 & 0.28 & 0.28 & 0.28 & 0.28 \\
\hline L-Threonine (98\%) & 0.31 & 0.31 & 0.31 & 0.31 & 0.31 \\
\hline L-Tryptophan (98\%) & 0.10 & 0.10 & 0.10 & 0.11 & 0.11 \\
\hline L-Valine & 0.19 & 0.19 & 0.19 & 0.19 & 0.20 \\
\hline Sepiolite & 0.33 & 0.02 & 0.28 & 0.3 & 0.27 \\
\hline Mycotoxin adsorbents ${ }^{8}$ & 0.10 & 0.10 & 0.10 & 0.10 & 0.10 \\
\hline$\beta$-glucanase and $\beta$-xylanase ${ }^{9}$ & 0.02 & 0.02 & 0.02 & 0.02 & 0.02 \\
\hline \multicolumn{6}{|l|}{ Calculated composition 10} \\
\hline $\mathrm{NE}(\mathrm{kcal} / \mathrm{kg})$ & 2470 & 2470 & 2470 & 2470 & 2470 \\
\hline Lysine $(\%)$ & 1.40 & 1.40 & 1.40 & 1.40 & 1.40 \\
\hline Methionine (\%) & 0.58 & 0.58 & 0.58 & 0.58 & 0.58 \\
\hline Methionine + cystine (\%) & 0.85 & 0.85 & 0.85 & 0.85 & 0.85 \\
\hline Threonine $(\%)$ & 0.98 & 0.98 & 0.98 & 0.98 & 0.98 \\
\hline Tryptophan (\%) & 0.32 & 0.32 & 0.32 & 0.33 & 0.32 \\
\hline Valine (\%) & 0.97 & 0.97 & 0.97 & 0.97 & 0.97 \\
\hline Neutral Detergent Fiber (\%) & 10.44 & 10.43 & 10.44 & 10.56 & 10.56 \\
\hline
\end{tabular}


Table 1. Cont.

\begin{tabular}{cccccc}
\hline Item & \multicolumn{5}{c}{ Diets ${ }^{\mathbf{1}}$} \\
\hline & $\mathbf{C}-$ & $\mathbf{C}+$ & PRO & PROC & PROP \\
\hline Analyzed chemical composition ${ }^{11}, \%$ & & & & & \\
Dry matter & 89.28 & 89.48 & 89.73 & 89.81 & 89.57 \\
Crude protein & 17.21 & 17.82 & 17.48 & 17.14 & 17.84 \\
Neutral detergent fiber & 11.17 & 11.44 & 11.66 & 12.85 & 12.34 \\
Acid detergent fiber & 3.80 & 3.77 & 4.12 & 4.95 & 4.23 \\
Acid detergent lignin & 0.70 & 0.70 & 0.74 & 0.85 & 0.78 \\
Total dietary fiber & 13.51 & 14.13 & 14.76 & 13.28 & 14.92 \\
$\quad$ Insoluble fiber & 12.27 & 12.92 & 13.26 & 12.14 & 12.91 \\
Soluble fiber & 1.24 & 1.20 & 1.50 & 1.13 & 2.00 \\
\hline
\end{tabular}

${ }^{1}$ Dietary treatment: $\mathrm{C}-$ : negative control diet; $\mathrm{C}+$ : positive control diet; PRO: diet with probiotic; PROC: diet with probiotic plus 5\% carob meal; PROP: diet with probiotic plus $5 \%$ citrus pulp. ${ }^{2} \mathrm{HP}-300$ (Hamlet Protein, Horsens, Denmark). ${ }^{3}$ Palbio 50 RD (Bioibérica SA, Barcelona, Spain). ${ }^{4}$ INMUPROT 70, ingredient based on a blend of potato protein, egg meal, and soy-protein concentrate (INGASO FARM SL, Álava, Spain). ${ }^{5}$ Miya-Gold ${ }^{\circledR}$ $\mathrm{S}$, microbiological feed additive (4b1830) containing Clostridium butyricum (Clostridium butyricum Miyairi 588 (FERM BP-2789), MIYA-GOLD ${ }^{\circledR}$, Huvepharma ${ }^{\circledR}$, Antwerp, Belgium); providing per kg diet: $2.5 \times 10^{8}$ CFU. ${ }^{6}$ ZINCOTRAX (Andrés Pintaluba SA, Tarragona, Spain); providing per kg of diet: $2500 \mathrm{mg} \mathrm{Zn} .{ }^{7} \mathrm{The}$ premix supplied per kilogram of diet: vitamin A, 12,000 IU; vitamin $\mathrm{D}_{3}, 2000 \mathrm{IU}$; vitamin E, 50 IU; vitamin $\mathrm{K}_{3}, 2$ mg; vitamin $\mathrm{B}_{1}, 1.5 \mathrm{mg}$; vitamin $\mathrm{B}_{2}, 4 \mathrm{mg}$; vitamin $\mathrm{B}_{6}, 3 \mathrm{mg}$; vitamin $\mathrm{B}_{12}, 0.035 \mu \mathrm{g}$; nicotinic acid, $26 \mathrm{mg}$; D-pantothenic acid, $15 \mathrm{mg}$; folic acid, $1 \mathrm{mg}$; choline, $200 \mathrm{mg}$; biotin, $0.18 \mathrm{mg} ; \mathrm{Fe}, 125 \mathrm{mg}$ as iron carbonate; Cu, $10 \mathrm{mg}$ as copper sulfate pentahydrate; $\mathrm{Zn}, 120 \mathrm{mg}$ as zinc oxide; Mn, $45 \mathrm{mg}$ as manganese (II) oxide; I, $0.8 \mathrm{mg}$ as calcium iodate selenium, $0.3 \mathrm{mg}$ as sodium selenite; $750 \mathrm{FYT}$ as 6-Phytase EC 3.1.3.26. ${ }^{8}$ TOXY-NIL ${ }^{\circledR}$ Plus Dry (Nutriad, Turnhout Belgium). ${ }^{9}$ Axtra ${ }^{\circledR}$ XB 201 TPT (Danisco Animal Nutrition, Madrid, Spain). ${ }^{10}$ According to the Fundación Española para el Desarrollo de la Nutrición Animal [19]. ${ }^{11}$ Each dietary treatment was analyzed in duplicate.

\subsection{Sampling Collection}

On day 25 of the experiment, after a period of $8 \mathrm{~h}$ of fasting, blood samples were obtained from the jugular vein of the piglets by venipuncture, using a $4 \mathrm{~mL}$ vacuum tube per animal (Z Serum Clot Activator, VACUETTE ${ }^{\circledR}$, Greiner Bio-One GmbH, Kremsmünster, Austria). Next, in the laboratory, they were centrifuged at $2500 \times g$ for $10 \mathrm{~min}$ to obtain serum, which was stored in aliquots at $-80{ }^{\circ} \mathrm{C}$ for the subsequent determination of the blood biochemical profile and cytokines. In addition, individual fecal samples were collected on day 26 of the trial directly from the anus of each piglet and placed in a sterile bottle for fecal microbiology analysis.

On the last day of the trial (day 27), prior to animal slaughtering, individual fecal samples were collected for chemical analysis, then the piglets were tranquilized with an intramuscular injection of azaperone, and later euthanized with an intravenous overdose of pentobarbital. They were bled, and their abdomens were immediately opened by an incision from sternum to pubis to remove the entire digestive tract. Samples were taken from the content of the stomach, duodenum, jejunum, ileum, cecum, and colon. The $\mathrm{pH}$ of these samples was immediately determined from the different sections of the gastrointestinal tract by insertion of a pH meter electrode (pH-Meter GLP 21, Crison Instruments, S.A., Alella, Barcelona, Spain), except for the colon where the $\mathrm{pH}$ determination was recorded according to the procedure described by Peters et al. [34]. Additionally, the ileal content was collected for chemical analysis.

The fecal and ileal content were lyophilized and stored at $-20^{\circ} \mathrm{C}$ in airtight containers until $\mathrm{TiO}_{2}$ analysis in the laboratory. In addition, sub-samples of fecal and cecum content $(1 \mathrm{~g})$ were acidified with $0.032 \mathrm{~mL}$ of $\mathrm{H}_{2} \mathrm{SO}_{4}: \mathrm{H}_{2} \mathrm{O}(50: 50)$ dilution and stored at $-20{ }^{\circ} \mathrm{C}$ until volatile fatty acid (VFA) analysis.

For histomorphometrical and immunohistochemical analysis, samples of the piglets' middle section of jejunum and ileum were obtained $(2 \mathrm{~cm})$ and fixed in $10 \%$ buffered formaldehyde and, subsequently, embedded in paraffin wax. 


\subsection{Analysis of Feed, Digesta, and Feces}

The feed samples were ground to pass through a $1 \mathrm{~mm}$ sieve in a laboratory mill (RETSCH ZM 200 Ultra Centrifugal Mill; RETSCH, Hann, Germany). These samples were analyzed using the Association of Official Analytical Chemists (AOAC) procedures [35]: dry matter (DM) by the 934.01 method; crude protein (CP) by the 2001.11 method. Van Soest et al. [36] procedures were used to determine the neutral detergent fiber (NDF) and acid detergent fiber (ADF), analyzing the acid detergent lignin (ADL) through the solubilization of cellulose with $72 \% \mathrm{H}_{2} \mathrm{SOH}_{4}$.

Sub-samples of the feeds were ground to pass a $0.5 \mathrm{~mm}$ sieve (in the same mill indicated above) to analyze the total, insoluble, and soluble dietary fiber using the AOAC 991.43 enzymatic-gravimetric method with the Megazyme K-TDFR-100A/K-TDFR-200A 04/17 kit (Megazyme Ltd., County Wicklow, Ireland).

Furthermore, the marker $\left(\mathrm{TiO}_{2}\right)$ used to calculate digestibility was analyzed in the feeds, feces, and ileum contents using the method described by Myers et al. [37]. For this analysis, the samples were also ground to pass through a $0.5 \mathrm{~mm}$ sieve. Feces and ileal contents were also analyzed for $\mathrm{CP}$, as it was indicated previously.

The VFA concentration in the cecum and feces was determined by capillary gas chromatography using an adaptation of the method described by Madrid et al. [38]. The gas chromatograph equipment used was a TRACE GC Ultra (Thermo Finnigan Italia SpA, Milan, Italy) with a flame ionization detector, and the capillary column was fused silica $(30 \mathrm{~m} \times 0.25 \mathrm{~mm} \times 0.25 \mu \mathrm{m}$ ID) coated with FFAP-TR as the stationary phase (Teknokroma, Barcelona, Spain). Standard solutions of acetic, propionic, butyric, isobutyric, isovaleric, and valeric acids were prepared for calibration, using 3-methyl-n-valeric acid as the internal standard as indicated by Oliveira et al. [39].

One gram of each collected fecal sample for microbial study was diluted with a sterile saline solution in a 1:10 dilution and homogenized on a mixer-homogenizer for $2 \mathrm{~min}$. Subsequently, aliquots of the ten-fold serial dilutions were spread-plated onto selective media. The dilutions were used for counting Enterobacteriaceae, coliforms, and lactic acid bacteria. Thus, the Enterobacteriaceae counts were determined by the ISO 21528-2:2004 [40] adapted method (RAPID' Enterobacteriaceae/Agar, Bio-Rad Laboratories, S.A., Madrid, Spain) (at $37^{\circ} \mathrm{C}$ for $24 \mathrm{~h}$ ). Coliform bacteria were enumerated using violet red bile lactose (VRBL) agar (at $37^{\circ} \mathrm{C}$ for $24 \mathrm{~h}$ ) according to ISO 4832:2006 [41]. Mesophilic lactic acid bacteria were enumerated using De Man, Rogosa, and Sharpe (MRS) agar (at $30{ }^{\circ} \mathrm{C}$ for $72 \mathrm{~h}$ ) following ISO 15214:1998 [42] and the incubation was carried out with a double-layer MRS medium to provide anaerobic conditions. The results were expressed as $\log _{10} \mathrm{CFU}$ (colony-forming units)/g of feces.

\subsection{Histomorphometrical and Immunohistochemical Procedures}

Sections $(4 \mu \mathrm{m})$ of each intestinal tissue sample were stained with hematoxylin and eosin for the morphometric study. For this determination, a ZEISS Axioskop 40 microscope (Carl Zeiss, Oberkochen, Germany) was used with a Spot Insight camera, and the Spot Advanced software (Spot Imaging Solution, MI, USA). In each slide, the height and crypt depth of 10 villi were measured and the results were expressed in $\mu \mathrm{m}$. In addition, the villus height/crypt depth ratio was determined. The number of intraepithelial lymphocytes and goblet cells was quantified by counting in 10 fields of epithelium of 25,000 $\mathrm{\mu m}^{2}$.

For immunohistochemical analyses, the detection of IgA-secretory cells in the jejunum and ileum was performed by the avidin-biotin-peroxidase complex technique, according to Oliveira et al. [39]. In the intestinal lamina propria, the number of IgA-positive cells was checked with a ZEISS Axioskop 40 microscope (Carl Zeiss, Oberkochen, Germany) using a Spot Insight camera and the Spot Advanced software (Spot Imaging Solution, MI, USA). Immunolabeled cells were recorded in 10 non-overlapping consecutive fields of $25,000 \mu \mathrm{m}^{2}$.

The same researcher, blinded to the treatments, performed the morphometric and immunohistochemical determinations. 


\subsection{Serum Analysis}

The serum metabolic profile was analyzed for glucose, urea, total cholesterol, triglycerides, total bilirubin, total protein, albumin, aspartate aminotransferase (AST), and alanine aminotransferase (ALT) using commercially available kits (Beckman Coulter Inc., Fullerton, CA, USA). The total antioxidant capacity (TAC) and total oxidative status (TOS) were measured according to Erel [43,44], using colorimetric assays. All analyses were executed in an automated chemistry analyzer (Olympus AU600, Olympus Europe GmbH, Hamburg, Germany).

Serum cytokine levels were assayed after centrifugation of the samples at $20,000 \times g$ to eliminate the lipid phase. Interleukin (IL)-1 $\beta$, IL-6, IL-8, IL-10, IL-12, and tumor necrosis factor$\alpha(\mathrm{TNF}-\alpha)$ were determined using a porcine-specific multiplex cytokine/chemokine assay (cat. no. PCYTMAG-23K; Millipore MILLIPLEX, Billerica, MA, USA) on a MAGPIX instrument (Luminex; Luminex Technologies, Austin, TX, USA), as indicated by the manufacturer.

\subsection{Calculations and Statistical Analyses}

The apparent fecal and ileal digestibility of DM and $\mathrm{CP}$ were determined by the digestibility equation as follows:

Digestibility $(\%)=\left[1-\left(\frac{\% \mathrm{TiO}_{2} \text { in feed }}{\% \mathrm{TiO}_{2} \text { in feces or ileum digesta }} \times \frac{\% \text { Nutrient in feces or ileum digesta }}{\% \text { Nutrient in feed }}\right)\right] \times 100$

All statistical analyses were performed using the SPSS Statistics software (IBM Corporation, Armonk, NY, USA), with the piglet set as the experimental unit. Data were analyzed by one-way ANOVA. The Shapiro-Wilks test was performed to assess the normality of data from the serum study; a logarithmic scale transformation was performed when the data did not follow normal distribution. Pairwise comparisons of means were performed using the Tukey test. Significance was determined at $p<0.05$, and a trend was assumed at $0.05 \leq p<0.10$.

\section{Results}

\subsection{Body Weight, Digestibility, and Digesta $p H$}

The body weights and average daily gains of the piglets were not affected $(p \geq 0.05)$ by the dietary treatments (Table 2). Furthermore, no effect of the feeds on the apparent ileal digestibility of DM was found $(p \geq 0.05)$, although a significant effect $(p<0.05)$ of dietary treatments on the apparent fecal digestibility of DM was observed. Thus, the fecal digestibility of DM was lower for the C - treatment than for C+ $(78.93 \%$ versus $83.80 \%$, respectively); $\mathrm{PRO}, \mathrm{PROC}$, and $\mathrm{PROP}$ treatments reached intermediate values, having no differences with $\mathrm{C}-$ or $\mathrm{C}+$. In addition, dietary treatments did not affect apparent fecal and ileal digestibility of $\mathrm{CP}(p \geq 0.05)$.

The digesta $\mathrm{pH}$ of the stomach, duodenum, jejunum, ileum, and colon was not affected $(p \geq 0.05)$ by the treatments. Only a slight trend was detected in the $\mathrm{pH}$ of the cecum content $(p<0.1)$, with $C+$ obtaining the higher value. 
Table 2. Body weight, average daily gain (ADG), apparent ileal and fecal digestibility of dry matter and crude protein, and digesta $\mathrm{pH}$ values of piglets fed experimental diets.

\begin{tabular}{|c|c|c|c|c|c|c|c|}
\hline \multicolumn{8}{|c|}{ Diets $^{1}$} \\
\hline Item & $\mathrm{C}-$ & $\mathrm{C}+$ & PRO & PROC & PROP & SEM $^{2}$ & $p$-Value \\
\hline \multicolumn{8}{|c|}{ Body weight (kg) } \\
\hline $0 \mathrm{~d}$ & 4.96 & 4.91 & 5.15 & 5.13 & 5.08 & 0.150 & 0.979 \\
\hline $14 \mathrm{~d}$ & 7.29 & 7.14 & 7.78 & 7.43 & 7.74 & 0.211 & 0.842 \\
\hline $26 \mathrm{~d}$ & 11.23 & 10.48 & 11.93 & 10.99 & 11.97 & 0.368 & 0.669 \\
\hline \multicolumn{8}{|l|}{$\operatorname{ADG}(\mathrm{kg} / \mathrm{d})$} \\
\hline $0-14 \mathrm{~d}$ & 0.167 & 0.161 & 0.187 & 0.164 & 0.189 & 0.009 & 0.726 \\
\hline $14-26 \mathrm{~d}$ & 0.328 & 0.278 & 0.345 & 0.296 & 0.352 & 0.016 & 0.569 \\
\hline $0-26 \mathrm{~d}$ & 0.243 & 0.216 & 0.256 & 0.225 & 0.265 & 0.011 & 0.642 \\
\hline \multicolumn{8}{|c|}{ Apparent digestibility } \\
\hline $\mathrm{DM}^{3}(\%)$ & 65.27 & 66.45 & 67.09 & 67.32 & 66.51 & 1.734 & 0.991 \\
\hline $\mathrm{CP}^{4}(\%)$ & 67.37 & 69.81 & 71.46 & 68.24 & 70.39 & 1.731 & 0.916 \\
\hline \multicolumn{8}{|l|}{ Fecal } \\
\hline DM (\%) & $78.93^{b}$ & $83.80^{\mathrm{a}}$ & $81.38^{a b}$ & $82.49^{a b}$ & $82.51^{a b}$ & 0.425 & 0.013 \\
\hline $\mathrm{CP}(\%)$ & 79.04 & 83.04 & 80.01 & 81.87 & 82.33 & 0.731 & 0.398 \\
\hline \multicolumn{8}{|c|}{ Digesta $\mathrm{pH}$ values } \\
\hline Stomach & 3.69 & 3.34 & 2.63 & 3.06 & 3.18 & 0.224 & 0.760 \\
\hline Duodenum & 5.16 & 5.69 & 5.97 & 5.89 & 6.18 & 0.258 & 0.749 \\
\hline Jejunum & 6.20 & 6.53 & 6.36 & 6.80 & 6.44 & 0.070 & 0.114 \\
\hline Ileum & 6.80 & 7.01 & 7.05 & 7.24 & 6.72 & 0.088 & 0.376 \\
\hline Cecum & 5.65 & 6.20 & 5.83 & 5.85 & 5.71 & 0.063 & 0.088 \\
\hline Colon & 5.83 & 6.19 & 6.09 & 5.84 & 6.02 & 0.075 & 0.518 \\
\hline
\end{tabular}

${ }^{1}$ Dietary treatment-C-: negative control diet; $\mathrm{C}+$ : positive control diet; PRO: diet with probiotic; PROC: diet with probiotic plus $5 \%$ carob meal; PROP: diet with probiotic plus $5 \%$ citrus pulp. ${ }^{2}$ SEM-standard error of the mean: $n=6$ replicates per treatment. ${ }^{3}$ DM-dry matter. ${ }^{4} \mathrm{CP}$ - crude protein. ${ }^{\mathrm{ab}}$ Means with different superscripts in the same row are different $(p<0.05)$.

\subsection{Microbiology and VFAs}

The Enterobacteriaceae, coliform, and lactic acid bacteria counts from the piglet feces were not significantly affected by the dietary treatments $(p \geq 0.05)$ (Table 3).

Table 3. Microbiology profile of feces from piglets fed the experimental diets at 26 days post-weaning.

\begin{tabular}{cccccccc}
\hline \multicolumn{7}{c}{ Diets $^{\mathbf{1}}$} \\
\hline Item & $\mathbf{C}-$ & $\mathbf{C}+$ & PRO & PROC & PROP & SEM $^{2}$ & $p$-Value \\
\hline Bacterial population & & & & & & & \\
(log 10 CFU/g feces) & & & & & & & \\
Enterobacteriaceae & 5.89 & 6.18 & 5.63 & 6.11 & 5.50 & 0.287 & 0.929 \\
Coliform bacteria & 5.80 & 6.14 & 5.48 & 6.05 & 5.31 & 0.282 & 0.859 \\
Lactic acid bacteria & 7.30 & 6.95 & 7.94 & 7.46 & 7.48 & 0.145 & 0.135 \\
\hline
\end{tabular}

${ }^{1}$ Dietary treatment-C--: negative control diet; C+: positive control diet; PRO: diet with probiotic; PROC: diet with probiotic plus $5 \%$ carob meal; PROP: diet with probiotic plus $5 \%$ citrus pulp. ${ }^{2}$ SEM-standard error of the mean: $n=6$ replicates per treatment.

The total concentration of VFAs in the cecum tended to be different among treatments $(p<0.1)$ (Table 4). The $\mathrm{C}+$ treatment had the lowest level $(55.54 \mathrm{mmol} / \mathrm{kg})$, although this value did not differ from the other treatments, except for the C-group, which had the highest cecum VFA concentration $(93.44 \mathrm{mmol} / \mathrm{kg})$. In addition, a dietary effect was not observed $(p \geq 0.05)$ on the fermentation profile (VFA molar $\%$ ) in the cecum. 
Table 4. Concentration of volatile fatty acids (VFAs) and fermentation profile in cecum and feces from piglets fed the experimental diets.

\begin{tabular}{|c|c|c|c|c|c|c|c|}
\hline \multicolumn{8}{|c|}{ Diets $^{1}$} \\
\hline Item & $\mathrm{C}-$ & $\mathrm{C}+$ & PRO & PROC & PROP & SEM $^{2}$ & $p$-Value \\
\hline \multicolumn{8}{|l|}{ Cecum } \\
\hline Total VFAs (mmol/kg) & $93.44^{\mathrm{a}}$ & $55.54^{b}$ & $76.38^{a b}$ & $78.72^{a b}$ & $77.96^{\mathrm{ab}}$ & 3.868 & 0.066 \\
\hline Acetic acid (molar \%) & 57.35 & 60.97 & 55.28 & 59.05 & 57.89 & 1.304 & 0.740 \\
\hline Propionic acid (molar \%) & 24.89 & 20.21 & 24.67 & 22.68 & 22.94 & 0.672 & 0.213 \\
\hline Butyric acid (molar \%) & 13.41 & 12.45 & 14.10 & 13.10 & 14.33 & 0.854 & 0.961 \\
\hline Isobutyric acid (molar \%) & 0.30 & 0.97 & 0.43 & 0.68 & 0.33 & 0.090 & 0.192 \\
\hline Isovaleric acid (molar \%) & 0.28 & 1.16 & 0.42 & 0.70 & 0.31 & 0.111 & 0.115 \\
\hline Valeric acid (molar \%) & 3.74 & 4.21 & 5.07 & 3.76 & 4.17 & 0.425 & 0.856 \\
\hline \multicolumn{8}{|l|}{ Feces } \\
\hline Total VFAs (mmol/kg) & $105.02^{a b}$ & $66.76^{\mathrm{b}}$ & $93.18^{\mathrm{ab}}$ & $121.42^{\mathrm{a}}$ & $114.90^{\mathrm{ab}}$ & 5.630 & 0.049 \\
\hline Acetic acid (molar \%) & $71.41^{a b}$ & $74.41^{\mathrm{a}}$ & $67.25^{a b}$ & $64.26^{\mathrm{b}}$ & $68.43^{a b}$ & 0.934 & 0.031 \\
\hline Propionic acid (molar \%) & 15.65 & 16.43 & 16.62 & 17.83 & 16.88 & 0.494 & 0.705 \\
\hline Butyric acid (molar \%) & $5.36^{\mathrm{ab}}$ & $3.16^{b}$ & $8.67^{\mathrm{a}}$ & $8.95^{\mathrm{a}}$ & $7.96^{\mathrm{a}}$ & 0.495 & 0.009 \\
\hline Isobutyric acid (molar \%) & 1.82 & 1.79 & 2.04 & 1.97 & 1.69 & 0.192 & 0.979 \\
\hline Isovaleric acid (molar \%) & 2.40 & 2.32 & 2.60 & 2.54 & 2.09 & 0.284 & 0.982 \\
\hline Valeric acid (molar \%) & 3.35 & 1.87 & 2.81 & 4.41 & 2.92 & 0.302 & 0.152 \\
\hline
\end{tabular}

${ }^{1}$ Dietary treatment-C-: negative control diet; $\mathrm{C}+$ : positive control diet; PRO: diet with probiotic; PROC: diet with probiotic plus $5 \%$ carob meal; PROP: diet with probiotic plus 5\% citrus pulp. ${ }^{2}$ SEM-standard error of the mean: $n=6$ replicates per treatment. ${ }^{\text {ab }}$ Means with different superscripts in the same row are different $(p<0.05)$.

However, the total VFA concentration in the feces was significantly different among treatments $(p<0.05)$. The VFA concentration in the $\mathrm{C}+$ treatment $(66.76 \mathrm{mmol} / \mathrm{kg})$ was at a lower value than in PROC $(121.42 \mathrm{mmol} / \mathrm{kg})$, while $\mathrm{C}-$, PRO, and PROP reached intermediate levels. Regarding the VFA molar proportion of the feces, a significant dietary effect on acetic acid was observed $(p<0.05)$. The $\mathrm{C}+$ treatment obtained a higher percentage of acetic acid (74.41 molar \%) than PROC (64.26 molar \%), with C-, PRO, and PROP having intermediate values. Additionally, significant effects were found on the molar percentage of butyric acid $(p<0.01)$; in this case, the $C+$ treatment had a lower molar proportion of butyric acid (3.16 molar \%) than the three treatments with probiotic $(8.67,8.95$, and 7.96 molar \% for PRO, PROC, and PROP, respectively), while the C - treatment had an intermediate molar proportion of butyric acid (5.36 molar \%), and no differences with the rest of the treatments.

\subsection{Histomorphometrical and Immunohistochemical Intestinal Measurements}

Table 5 presents the effects of the dietary treatments on the histomorphometrical and immunohistochemical intestinal parameters of the piglets. Villi height, crypt depths, and villus height/crypt depth ratios, both in the jejunum and in the ileum of the piglets, were not affected $(p \geq 0.05)$ by the treatments. Similarly, the number of goblet cells and lymphocytes from both intestinal sections were also not affected by the dietary treatments $(p \geq 0.05)$. Furthermore, as a result of the immunohistochemical study of the jejunum and ileum, it was found that the experimental diets had no effect on the IgA cell count $(p \geq 0.05)$. 
Table 5. Histomorphometrical and immunohistochemical intestinal parameters from piglets fed the experimental diets.

\begin{tabular}{|c|c|c|c|c|c|c|c|}
\hline \multicolumn{8}{|c|}{ Diets $^{1}$} \\
\hline Item & $\mathrm{C}-$ & $\mathrm{C}+$ & PRO & PROC & PROP & SEM $^{2}$ & $p$-Value \\
\hline \multicolumn{8}{|l|}{ Jejunum } \\
\hline Villus height $(\mu \mathrm{m})$ & 508.72 & 422.90 & 551.92 & 481.22 & 555.67 & 16.656 & 0.151 \\
\hline Crypt depth ( $\mu \mathrm{m})$ & 237.42 & 288.40 & 266.90 & 267.45 & 271.12 & 6.148 & 0.202 \\
\hline Villus/crypt ratio & 2.23 & 1.50 & 2.08 & 1.82 & 2.09 & 0.083 & 0.103 \\
\hline Goblet cells ${ }^{3}$ & 0.50 & 0.96 & 0.40 & 0.30 & 0.40 & 0.094 & 0.304 \\
\hline Lymphocytes $^{3}$ & 18.70 & 19.93 & 18.35 & 15.92 & 15.55 & 0.825 & 0.437 \\
\hline IgA cells $^{3}$ & 10.25 & 11.10 & 14.225 & 14.12 & 9.47 & 0.839 & 0.260 \\
\hline \multicolumn{8}{|l|}{ Ileum } \\
\hline Villus height $(\mu \mathrm{m})$ & 411.70 & 426.83 & 485.40 & 409.42 & 427.70 & 15.756 & 0.534 \\
\hline Crypt depth $(\mu \mathrm{m})$ & 219.15 & 249.50 & 256.60 & 228.92 & 256.70 & 7.866 & 0.438 \\
\hline Villus/crypt ratio & 1.92 & 1.72 & 1.90 & 1.85 & 1.73 & 0.066 & 0.824 \\
\hline Goblet cells & 1.05 & 1.13 & 0.80 & 0.92 & 0.95 & 0.138 & 0.955 \\
\hline Lymphocytes & 15.70 & 14.23 & 16.40 & 15.37 & 14.05 & 0.612 & 0.713 \\
\hline IgA cells & 11.47 & 6.53 & 8.87 & 10.47 & 6.07 & 1.008 & 0.388 \\
\hline
\end{tabular}

${ }^{1}$ Dietary treatment-C-: negative control diet; $\mathrm{C}+$ : positive control diet; PRO: diet with probiotic; PROC: diet

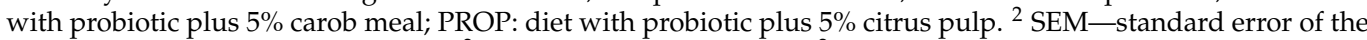
mean: $n=6$ replicates per treatment. ${ }^{3}$ Number of cells $/ 25,000 \mu \mathrm{m}^{2}$.

\subsection{Serum Parameters}

The effects of feeding with experimental diets on the general biochemical parameters, oxidative status indicators, and cytokines in the serum of piglets at day 25 of the trial are displayed in Table 6 . In general, no differences were found $(p \geq 0.05)$ in the serum biochemical parameters; only a tendency was observed $(p<0.1)$ in the ALT serum, which reached a higher enzymatic activity in $\mathrm{C}+$ than in the PROC treatment (115.42 versus $71.30 \mathrm{IU} / \mathrm{L}$, respectively), and no differences with the rest of the treatments. In addition, the oxidative status indicators (TAC and TOS) in the serum were not affected $(p \geq 0.05)$ by the dietary treatments.

Table 6. General biochemical parameters, oxidative balance indicators and cytokines in serum of piglets feed with experimental diets at 25 days post-weaning.

\begin{tabular}{|c|c|c|c|c|c|c|c|}
\hline \multicolumn{8}{|c|}{ Diets $^{1}$} \\
\hline Item & $\mathrm{C}-$ & $\mathrm{C}+$ & PRO & PROC & PROP & SEM $^{2}$ & $p$-Value \\
\hline \multicolumn{8}{|l|}{ Biochemical parameters } \\
\hline Glucose $(\mathrm{mg} / \mathrm{dL})$ & 83.60 & 81.40 & 91.22 & 85.35 & 92.70 & 2.932 & 0.759 \\
\hline Urea (mg/dL) & 27.25 & 25.70 & 28.53 & 26.98 & 28.50 & 1.029 & 0.848 \\
\hline Cholesterol (mg/dL) & 89.07 & 74.97 & 80.25 & 76.25 & 92.57 & 4.258 & 0.626 \\
\hline Triglycerides (mg/dL) & 45.13 & 31.73 & 31.74 & 41.34 & 33.99 & 2.567 & 0.417 \\
\hline Total Bilirubin (mg/dL) & 0.230 & 0.197 & 0.170 & 0.165 & 0.195 & 0.014 & 0.625 \\
\hline Total Proteins (g/dL) & 4.81 & 4.65 & 4.80 & 5.20 & 4.98 & 0.110 & 0.620 \\
\hline Albumin (g/dL) & 2.48 & 2.16 & 2.37 & 2.57 & 2.65 & 0.080 & 0.348 \\
\hline Albumin/Globulin ratio & 1.07 & 0.87 & 0.97 & 1.00 & 1.14 & 0.042 & 0.361 \\
\hline$(\mathrm{AST})(\mathrm{IU} / \mathrm{L})^{3}$ & 94.44 & 65.75 & 68.82 & 65.44 & 75.92 & 5.593 & 0.525 \\
\hline$(\mathrm{ALT})(\mathrm{IU} / \mathrm{L})^{4}$ & $89.87^{a b}$ & $115.42^{\mathrm{a}}$ & $86.40^{a b}$ & $71.30^{b}$ & $84.05^{a b}$ & 4.393 & 0.089 \\
\hline \multicolumn{8}{|l|}{ Oxidative balance indicators } \\
\hline $\operatorname{TOS}(\mu \mathrm{mol} / \mathrm{L})^{5}$ & 13.94 & 12.05 & 8.57 & 10.35 & 11.50 & 1.286 & 0.762 \\
\hline TAC $(\mathrm{mmol} / \mathrm{L})^{6}$ & 0.824 & 0.776 & 0.768 & 0.746 & 0.777 & 0.010 & 0.227 \\
\hline \multicolumn{8}{|l|}{ Cytokines } \\
\hline $\mathrm{IL}-1 \beta(\mathrm{ng} / \mathrm{mL})$ & 0.064 & 0.144 & 0.061 & 0.091 & 0.096 & 0.020 & 0.803 \\
\hline IL- 6 (ng/mL) & 0.018 & 0.088 & 0.018 & 0.031 & 0.034 & 0.014 & 0.628 \\
\hline IL- 8 (ng/mL) & $3.346^{\mathrm{a}}$ & $2.992^{\mathrm{a}}$ & $3.043^{\mathrm{a}}$ & $1.145^{b}$ & $2.219^{a b}$ & 0.272 & 0.036 \\
\hline IL-10 (ng/mL) & 0.389 & 1.958 & 0.252 & 0.384 & 1.022 & 0.358 & 0.641 \\
\hline IL- 12 (ng/mL) & 3.453 & 3.071 & 3.835 & 3.249 & 2.749 & 0.196 & 0.448 \\
\hline $\mathrm{TNF}-\alpha(\mathrm{ng} / \mathrm{mL})$ & 0.080 & 0.078 & 0.078 & 0.086 & 0.088 & 0.002 & 0.627 \\
\hline
\end{tabular}

${ }^{1}$ Dietary treatment-C-: negative control diet; $\mathrm{C}+$ : positive control diet; PRO: diet with probiotic; PROC: diet with probiotic plus $5 \%$ carob meal; PROP: diet with probiotic plus $5 \%$ citrus pulp. ${ }^{2}$ SEM—-standard error of the mean: $n=6$ replicates per treatment. ${ }^{3}$ AST—aspartate aminotransferase. ${ }^{4}$ ALT-alanine aminotransferase. ${ }^{5}$ TOS — total oxidant status. ${ }^{6}$ TAC—-total antioxidant capacity. ${ }^{\text {ab }}$ Means with different superscripts in the same row are different $(p<0.05)$. 
Regarding the effect of the diets on the serum cytokine level, no significant effects ( $p \geq 0.05$ ) on IL-1 $\beta$, IL-6, IL-10, IL-12, or TNF- $\alpha$ were found; however, the IL-8 concentration was significantly $(p<0.05)$ lower for the PROC treatment compared to the $\mathrm{C}-, \mathrm{C}+$, and PRO treatments ( 1.145 versus 3.346, 2.992, and $3.043 \mathrm{ng} / \mathrm{mL}$, respectively), while the PROP treatment obtained intermediate levels $(2.219 \mathrm{ng} / \mathrm{mL})$.

\section{Discussion}

Restrictions on high-level $\mathrm{ZnO}$ usage in piglet feed is a major challenge for the sustainability of the current levels of intensive pig production [4]. There are many changes related to the handling, environmental, and feeding conditions that need to be addressed. Therefore, with a view to optimizing piglet feed that is free from restricted substances, exhaustive studies need to be performed.

In our experiment, the inclusion of Clostridium butyricum in feeds without high levels of $\mathrm{ZnO}$, alone or in combination with carob meal or citrus pulp, did not affect the body weight or weigh gain of piglets after weaning, compared to both control feeds (with or without $\mathrm{ZnO}$ ). Chen et al. [11] found similar results when weaned piglets were fed Clostridium butyricum in increasing doses, compared to a negative control diet. Regarding the inclusion of carob meal, authors such as Špoljarić et al. [45] observed an improvement in the body weight of piglets at 42 days post-weaning when the feed was supplemented with $4 \%$ carob whole meal, although this effect was not found at 28 days post-weaning by these authors. The effect of including citrus pulp in feed on the body weight or weight gain of weaned piglets showed varying results, depending on the percentage of the ingredient that was included. Almeida et al. [31] found no negative effect on body weight when they incorporated 7.5\% citrus pulp in the feed of weaned piglets, although Pascoal et al. [27] showed negative results on weight gain when this ingredient was incorporated at $9 \%$. It should be highlighted that despite of the fact that our trial diets did not show negative effects on the growth of the animals, they could affect the intake or the feed conversion ratio, so performance tests should be carried out to evaluate these potential effects.

The apparent ileal digestibility (of DM or $\mathrm{CP}$ ) was not affected by the treatments, although the apparent fecal digestibility of DM improved by $5 \%$ with the $C+$ (high level of $\mathrm{ZnO}$ ) treatment when compared to $\mathrm{C}-$; in addition, in spite of fecal $\mathrm{CP}$ digestibility not being significantly altered by treatments, $C+$ reached a quantitatively higher value than C-. Dębski [46] indicated that dietary Zn supplementation is used to reduce the fermentation of nutrients in the intestine, improving nutrient digestibility. The inclusion of Clostridium butyricum, alone or in combination with carob meal or citrus pulp, did not result in a difference in $\mathrm{C}+$, and neither in $\mathrm{C}-$, where fecal DM digestibility reached intermediate levels. Han et al. [47] suggested that supplementation with Clostridium butyricum increased total tract digestibility, as it increased the concentrations of the VFAs that reduce gut $\mathrm{pH}$, achieving an anti-bacterial effect and increasing butyrate, which provides energy for intestinal epithelial cells. In addition, these authors indicated that this effect was more marked when the diet was supplemented with a higher level of probiotic $\left(2.5 \times 10^{9} \mathrm{CFU} / \mathrm{kg}\right.$ of Clostridium butyricum).

We hypothesized that the inclusion of a combination of Clostridium butyricum plus carob meal or citrus pulp could generate a positive complementary effect on the intestinal environment. The probiotic could help to improve digestive tract health; and the fiber ingredients could provide an additional favorable environment for beneficial bacteria. In this way, it can be said that, depending on the physicochemical properties of the fiber diet, the effects could be different [48]. Soluble fiber is more fermentable, and it may produce an increase in VFAs that affects the intestinal environment; insoluble fiber may reduce the digesta transit time, preventing the proliferation of pathogenic bacteria [49]. In addition, different effects resulting from the amount, type of fiber, and post-weaning period that were applied have been noted [50]. In our trial, different fiber ingredients were used, but all diets were iso-NDF formulated, resulting in few analytical differences in the feeds, both in the Van Soest fractions and in dietary fiber. No additional improvements in digestibility 
nor harmful effects were found with the carob meal or citrus pulp at $5 \%$ inclusion. On the other hand, when Zhang et al. [51] evaluated the effects of Clostridium butyricum and corn bran at $5 \%$ on weaned piglets, they observed a decrease in digestibility, and no positive interaction between the corn bran and Clostridium butyricum. However, Chen et al. [50] evaluated the effects of dietary soluble and insoluble fiber inclusion (alone or in different combinations) on weaning piglets, and found that all treatments supplemented with fiber presented a higher apparent fecal digestibility of DM than the control group; and the effects on the ileum Lactobacillus content and cecum digesta VFAs depended on the type of dietary treatment.

In our study, despite finding that the treatments had no effect on the general population of Enterobacteriaceae, coliforms, or lactic acid bacteria in feces, the concentrations of VFAs were affected by the treatments. Therefore, a more exhaustive study of the microbiota is desirable for improving knowledge in this area. We found that the concentration of VFAs in feces with C+ was lower than that in the PROC treatment. O'Shea et al. [52] also found that $\mathrm{ZnO}$ in piglet feed decreased the VFA content in feces. They justified this fact with the implication that $\mathrm{ZnO}$ could have decreased the secretion of chloride from the colon mucosa; therefore, reducing the secretion of fluids, and contributing to a reduction in water in the digesta and an alteration of the microbial activity. On the other hand, although changes in the VFA profile in the cecum content were not observed, they were found in the feces. Thus, the diets that included the probiotic showed a higher molar percentage of butyric acid, in relation to the diet with high levels of $\mathrm{ZnO}$. Clostridium butyricum is a Gram-positive anaerobe that produces butyric acid, which could provide nutrients for the regeneration of intestinal epithelial cells, contributing to intestinal health [53].

It is known that the inclusion of $\mathrm{ZnO}$ at high levels increases the height of villi and decreases crypt depth, improving the villus height/crypt depth ratio [54,55], which could be related to a greater capacity for nutrient absorption in the small intestine. However, in our case, any dietary treatment, including the $\mathrm{ZnO}$, did not affect the histomorphology of the intestinal mucosa. Moreover, the number of goblet cells, lymphocytes, and IgA cells in the intestinal mucosa were also not affected. This could be related to the fact that the piglets were not subjected to challenging aggressions that could affect the intestinal mucosa, and they did not manifest diarrhea problems regardless. In this way, Liu et al. [56] indicated that the effect on the intestinal morphology of adding $\mathrm{Zn}$ into piglet diets, even at high doses, is limited under optimal physiological conditions.

In general, the dietary treatments in our trial did not affect the serum biochemistry profile of the piglets. In addition, the levels of glucose, urea, cholesterol, triglycerides, total bilirubin, total proteins, albumin, and the albumin/globulin ratio were within the ranges indicated by Perri et al. [57] and Ventrella et al. [58] for piglets close to weaning. The mean levels of ALT and AST enzymatic activity were within the reference ranges indicated by Caprarulo et al. [59], although these were close to the maximum levels observed by Klem et al. [60] for growing pigs. It should be noted that the ALT, a liver enzyme that, at high levels, is considered to be a biomarker of liver damage [61], was different for the PROC and C+ treatments. Neither the TOS or TAC values were affected by the treatment, which was evidenced by the absence of dietary effects on the oxidative status of the piglets. Despite the PROC treatment containing carob, an ingredient with high levels of phenolic compounds, potentially with an antioxidant effect, most of those are in the form of condensed tannins [62], a chemical form which is poorly bioavailable [63,64].

Many studies have determined that, during the inflammation of the gastrointestinal tract, there is an imbalance of the inflammatory cytokine profile [65]. In our experiment, the serum cytokines values were not altered by dietary treatments, except for the concentration of IL-8 in the PROC diet. Zinc at high levels in feeding piglets has shown different results on cytokines. Zhu et al. [55] found differences in the gene expression of certain cytokines from the jejunum mucosa when comparing piglets supplemented with $\mathrm{ZnO}$ (3000 ppm) with piglets that were fed a basal diet; specifically, a downregulated IL-1 $\beta$ expression (a pro-inflammatory cytokine) and an upregulated TGF- $\beta$ expression (an anti-inflammatory 
cytokine). Similarly, other authors observed a decrease in the expression of other proinflammatory cytokines, such as TNF- $\alpha$, IL- 6 , and IFN- $\gamma$, at day 7 post-weaning in piglets supplemented with high levels of $\mathrm{ZnO}$; however, no differences at day 14 post-weaning were found [66]. In addition, Kloubert et al. [67] studied Zn supplementation at 0, 100, and $2500 \mathrm{ppm}$ in the form of $\mathrm{ZnO}$ in weaned piglets, finding that the concentrations of IL-1 $\beta$, IL-6, or TNF- $\alpha$ in diluted whole blood cultures (incubated with or without substance stimulates of cytokine production such as lipopolysaccharide or phytohemagglutinin) from piglets with dietary treatments were not affected by Zn supplementation. However, IL-2 concentration (a pro-inflammatory cytokine) increased in peripheral blood mononuclear cell cultures (incubated with substance stimulates of cytokine production) from piglets supplemented with $2500 \mathrm{ppm}$ of Zn [67].

Regarding feed supplementation with probiotics, one study showed a decrease in the concentration of IL-1 $\beta$ in the serum of weaned piglets that were supplemented with Clostridium butyricum and challenged with enterotoxigenic Escherichia coli K88 [68]. In addition, other authors have found changes in the cytokine profile when probiotics were used in the feed of piglets challenged with Escherichia coli lipopolysaccharide [69], or affected by post-weaning colibacillosis [70]. Nevertheless, in our study, the general biochemical serum profile and other parameters that were evaluated indicated the absence of nutritional imbalances or harmful processes on the animals' health. In this sense, as cytokines are produced by the action of a stimulus, it could be hypothesized that, in favorable environmental situations, changes in their concentrations could be difficult to detect.

However, the PROC dietary treatment had the lowest IL- 8 cytokine value, which is a type of pro-inflammatory cytokine [65], being lower than that in the $\mathrm{C}-, \mathrm{C}+$, and PRO treatments. These results could be related to the inclusion of carob meal as an ingredient, since this feedstuff, or its derivates, has shown anti-inflammatory activity in in vitro assays and animal models [71,72]. Moreover, the advantageous effects of carob products on the other immunity parameters have been suggested. Špoljarić et al. [45] observed that supplementation with carob whole meal did not affect the amount of red blood cells or leucocytes in weaned pigs, but an increase in the proportions of various types of lymphoid cells in the peripheral blood was observed.

\section{Conclusions}

The results of this work showed that supplementation with Clostridium butyricum may improve the intestinal wellness status of piglets by increasing butyric acid, without alteration from the inclusion of carob meal or citrus pulp at $5 \%$, obtaining digestibility values comparable with the incorporation of high levels of $\mathrm{ZnO}$ in the diet. In addition, carob meal could decrease the concentration of serum IL-8 cytokine. Moreover, further studies on the gut microbiota and growth performance of piglets in commercial conditions would be desirable, as these effects could be different in more challenging environmental conditions.

Author Contributions: Conceptualization, S.M.-M., F.H. and J.M.; methodology, S.M.-M., J.M. and M.A.R.; formal analysis, M.L. and J.M.; investigation, M.L., M.J.L., F.J.P. and C.J.S.; resources, M.A.R. and J.C.S.; writing—original draft preparation, M.L., J.M., J.C.S., F.J.P. and S.M.-M.; writing—review and editing, M.L., F.H. and J.M.; supervision, S.M.-M., M.A.R. and F.H. All authors have read and agreed to the published version of the manuscript.

Funding: This research was funded by The European Regional Development Fund (ERDF), and by the Centre for the Development of Industrial Technology (CDTI) of Spanish Ministry of Science and Innovation, SAT Alia project, grant number IDI-20170544.

Institutional Review Board Statement: The study was conducted according to the protocol approved by the Ethics Committee of Animal Experimentation of the University of Murcia, and by the Government of the Region of Murcia (protocol code A13170502, date 31 May 2017), according to the Directive 2010/63/EU of the European Parliament and of the Council of 22 September 2010 on the protection of animals used for scientific purposes.

Informed Consent Statement: Not applicable. 
Data Availability Statement: Data sharing is not applicable to this article.

Conflicts of Interest: The authors have read the journal's policy and have the following competing interests: the co-authors (M.A.R., J.C.S.) are employees of Agrarian Transformation Society, number 2439. The other authors have no competing interests.

\section{References}

1. Piva, A.; Morlacchini, M.; Casadei, G.; Gatta, P.P.; Biagi, G.; Prandini, A. Sodium Butyrate Improves Growth Performance of Weaned Piglets during the First Period after Weaning. Ital. J. Anim. Sci. 2002, 1, 35-41. [CrossRef]

2. Heo, J.M.; Opapeju, F.O.; Pluske, J.R.; Kim, J.C.; Hampson, D.J.; Nyachoti, C.M. Gastrointestinal Health and Function in Weaned Pigs: A Review of Feeding Strategies to Control Post-Weaning Diarrhoea without Using in-Feed Antimicrobial Compounds. J. Anim. Physiol. Anim. Nutr. 2013, 97, 207-237. [CrossRef] [PubMed]

3. Ma, F.; Xu, S.; Tang, Z.; Li, Z.; Zhang, L. Use of Antimicrobials in Food Animals and Impact of Transmission of Antimicrobial Resistance on Humans. Biosaf. Health 2021, 3, 32-38. [CrossRef]

4. López-Gálvez, G.; López-Alonso, M.; Pechova, A.; Mayo, B.; Dierick, N.; Gropp, J. Alternatives to Antibiotics and Trace Elements (Copper and Zinc) to Improve Gut Health and Zootechnical Parameters in Piglets: A Review. Anim. Feed Sci. Tech. 2021, 271, 114727. [CrossRef]

5. Bednorz, C.; Oelgeschläger, K.; Kinnemann, B.; Hartmann, S.; Neumann, K.; Pieper, R.; Bethe, A.; Semmler, T.; Tedin, K.; Schierack, P.; et al. The Broader Context of Antibiotic Resistance: Zinc Feed Supplementation of Piglets Increases the Proportion of Multi-Resistant Escherichia coli in Vivo. Int. J. Med. Microbiol. 2013, 303, 396-403. [CrossRef]

6. Bonetti, A.; Tugnoli, B.; Piva, A.; Grilli, E. Towards Zero Zinc Oxide: Feeding Strategies to Manage Post-Weaning Diarrhea in Piglets. Animals 2021, 11, 642. [CrossRef]

7. Patil, A.K.; Kumar, S.; Verma, A.K.; Baghel, R.P.S. Probiotics as Feed Additives in Weaned Pigs: A Review. Livest. Res. Int. 2015, 3 , 31-39.

8. Meng, Q.W.; Yan, L.; Ao, X.; Zhou, T.X.; Wang, J.P.; Lee, J.H.; Kim, I.H. Influence of Probiotics in Different Energy and Nutrient Density Diets on Growth Performance, Nutrient Digestibility, Meat Quality, and Blood Characteristics in Growing-Finishing Pigs. J. Anim. Sci. 2010, 88, 3320-3326. [CrossRef]

9. Eur-Lex, Commission Implementing Regulation (EU) No 373/2011 of 15 April 2011 Concerning the Authorisation of the Preparation of Clostridium butyricum FERM-BP 2789 as a Feed Additive for Minor Avian Species except Laying Birds, Weaned Piglets and Minor Porcine Species (Weaned) and Amending Regulation (EC) No 903/2009 (Holder of Authorisation Miyarisan Pharmaceutical Co. Ltd., Represented by Miyarisan Pharmaceutical Europe, S.L.U.) Text with EEA Relevance 2011 (OJ L 102, 16.4.2011, p. 10-12). Available online: https:/ / eur-lex.europa.eu/legal-content/EN/ALL/?uri=CELEX\%3A32011R0373 (accessed on 6 June 2021).

10. Meimandipour, A.; Shuhaimi, M.; Soleimani, A.F.; Azhar, K.; Hair-Bejo, M.; Kabeir, B.M.; Javanmard, A.; Anas, O.M.; Yazid, A.M. Selected Microbial Groups and Short-Chain Fatty Acids Profile in a Simulated Chicken Cecum Supplemented with Two Strains of Lactobacillus. Poultry Sci. 2010, 89, 470-476. [CrossRef]

11. Chen, L.; Li, S.; Zheng, J.; Li, W.; Jiang, X.; Zhao, X.; Li, J.; Che, L.; Lin, Y.; Xu, S.; et al. Effects of Dietary Clostridium butyricum Supplementation on Growth Performance, Intestinal Development, and Immune Response of Weaned Piglets Challenged with Lipopolysaccharide. J. Anim. Sci. Biotechnol. 2018, 9, 62. [CrossRef]

12. Zhang, J.; Chen, X.; Liu, P.; Zhao, J.; Sun, J.; Guan, W.; Johnston, L.J.; Levesque, C.L.; Fan, P.; He, T.; et al. Dietary Clostridium butyricum Induces a Phased Shift in Fecal Microbiota Structure and Increases the Acetic Acid-Producing Bacteria in a Weaned Piglet Model. J. Agric. Food Chem. 2018, 66, 5157-5166. [CrossRef] [PubMed]

13. Zong, X.; Wang, T.H.; Lu, Z.Q.; Song, D.G.; Zhao, J.; Wang, Y.Z. Effects of Clostridium butyricum or in Combination with Bacillus licheniformis on the Growth Performance, Blood Indexes, and Intestinal Barrier Function of Weanling Piglets. Livest. Sci. 2019, 220, 137-142. [CrossRef]

14. Cao, G.; Tao, F.; Hu, Y.; Li, Z.; Zhang, Y.; Deng, B.; Zhan, X. Positive Effects of a Clostridium butyricum-Based Compound Probiotic on Growth Performance, Immune Responses, Intestinal Morphology, Hypothalamic Neurotransmitters, and Colonic Microbiota in Weaned Piglets. Food Funct. 2019, 10, 2926-2934. [CrossRef] [PubMed]

15. Markowiak, P.; Śliżewska, K. The Role of Probiotics, Prebiotics and Synbiotics in Animal Nutrition. Gut. Pathog. 2018, 10, 21. [CrossRef]

16. Fuller, R.; Gibson, G.R. Probiotics and Prebiotics: Microflora Management for Improved Gut Health. Clin. Microbiol. Infect. 1998, 4, 477-480. [CrossRef]

17. Slavin, J. Fiber and Prebiotics: Mechanisms and Health Benefits. Nutrients 2013, 5, 1417-1435. [CrossRef] [PubMed]

18. Chen, H.; Mao, X.; He, J.; Yu, B.; Huang, Z.; Yu, J.; Zheng, P.; Chen, D. Dietary Fibre Affects Intestinal Mucosal Barrier Function and Regulates Intestinal Bacteria in Weaning Piglets. Br. J. Nutr. 2013, 110, 1837-1848. [CrossRef]

19. Fundación Española para el Desarrollo de la Nutrición Animal (FEDNA). Tablas FEDNA de Composición y Valor Nutritivo de Alimentos Para La Fabricación de Piensos Compuestos; Fundación Española para el Desarrollo de la Nutrición Animal: Madrid, Spain, 2010.

20. Biner, B.; Gubbuk, H.; Karhan, M.; Aksu, M.; Pekmezci, M. Sugar Profiles of the Pods of Cultivated and Wild Types of Carob Bean (Ceratonia siliqua L.) in Turkey. Food Chem. 2007, 100, 1453-1455. [CrossRef] 
21. Durazzo, A.; Turfani, V.; Narducci, V.; Azzini, E.; Maiani, G.; Carcea, M. Nutritional Characterisation and Bioactive Components of Commercial Carobs Flours. Food Chem. 2014, 153, 109-113. [CrossRef]

22. Biagi, G.; Cipollini, I.; Paulicks, B.R.; Roth, F.X. Effect of Tannins on Growth Performance and Intestinal Ecosystem in Weaned Piglets. Arch. Anim. Nutr. 2010, 64, 121-135. [CrossRef]

23. Andrés-Elias, N.; Pujols, J.; Badiola, I.; Torrallardona, D. Effect of Nucleotides and Carob Pulp on Gut Health and Performance of Weanling Piglets. Livest. Sci. 2007, 108, 280-283. [CrossRef]

24. Lizardo, R.; Canellas, J.; Mas, F.; Torrallardona, D.; Brufau, J. L'utilisation de La Farine de Caroube Dans Les Aliments de Sevrage et Son Influence Sur Les Performances et La Santé Des Porcelets. J. Rech. Porcine 2002, 34, 97-101.

25. Putnik, P.; Bursać Kovačević, D.; Režek Jambrak, A.; Barba, F.J.; Cravotto, G.; Binello, A.; Lorenzo, J.M.; Shpigelman, A. Innovative "Green" and Novel Strategies for the Extraction of Bioactive Added Value Compounds from Citrus Wastes-A Review. Molecules 2017, 22, 680. [CrossRef] [PubMed]

26. Hotchkiss, A.; Manderson, K.; Olano-Martin, E.; Grace, W.; Gibson, G.; Rastall, R. Orange Peel Pectic Oligosaccharide Prebiotics with Food and Feed Applications. In Proceedings of the 228th American Chemical Society National Meeting, Philadelphia, PA, USA, 22-26 August 2004.

27. Pascoal, L.A.F.; Thomaz, M.C.; Watanabe, P.H.; Ruiz, U.D.S.; Amorim, A.B.; Daniel, E.; Silva, S.Z. Da Purified Cellulose, Soybean Hulls and Citrus Pulp as a Source of Fiber for Weaned Piglets. Sci. Agric. 2015, 72, 400-410. [CrossRef]

28. Collier, C.T.; Carroll, J.A.; Callaway, T.R.; Arthington, J.D. Oral Administration of Citrus Pulp Reduces Gastrointestinal Recovery of Orally Dosed Escherichia coli F18 in Weaned Pigs. J. Anim. Vet. Adv. 2010, 9, 2140-2145. [CrossRef]

29. Brambillasca, S.; Zunino, P.; Cajarville, C. Addition of Inulin, Alfalfa and Citrus Pulp in Diets for Piglets: Influence on Nutritional and Faecal Parameters, Intestinal Organs, and Colonic Fermentation and Bacterial Populations. Livest. Sci. 2015, 178, 243-250. [CrossRef]

30. Pascoal, L.A.F.; Thomaz, M.C.; Watanabe, P.H.; Ruiz, U.D.S.; Ezequiel, J.M.B.; Amorim, A.B.; Daniel, E.; Masson, G.C.I. Fiber Sources in Diets for Newly Weaned Piglets. Rev. Bras. Zootec. 2012, 41, 636-642. [CrossRef]

31. Almeida, V.V.; Nuñez, A.J.C.; Schinckel, A.P.; Alvarenga, P.V.A.; Castelini, F.R.; Silva-Guillen, Y.V.; Thomaz, M.C. Interactive Effect of Dietary Protein and Dried Citrus Pulp Levels on Growth Performance, Small Intestinal Morphology, and Hindgut Fermentation of Weanling Pigs. J. Anim. Sci. 2017, 95, 257-269. [CrossRef]

32. Eur-Lex, Directive 2010/63/EU of the European Parliament and of the Council of 22 September 2010 on the Protection of Animals Used for Scientific Purposes Text with EEA Relevance (OJ L 276, 20.10.2010, p. 33-79). Available online: https: / / eur-lex.europa.eu/legal-content/EN/TXT/?uri=celex\%3A32010L0063 (accessed on 15 May 2021).

33. Fundación Española para el Desarrollo de la Nutrición Animal (FEDNA). Necesidades Nutricionales Para Ganado Porcino Normas FEDNA; Fundación Española para el Desarrollo de la Nutrición Animal: Madrid, Spain, 2013.

34. Peters, J.; Combs, S.; Hoskins, B.; Jarman, J.; Kovar, J.; Watson, M.; Wolf, A.; Wolf, N. Recommended Methods of Manure Analysis. A3769; University of Wisconsin, Cooperative Extension Publishing: Madison, WI, USA, 2003.

35. Association of Official Analytical Chemists (AOAC). Official Methods of Analysis of AOAC International, 18th ed.; AOAC International: Gaithersburg, MD, USA, 2006.

36. Van Soest, P.J.; Robertson, J.B.; Lewis, B.A. Methods for Dietary Fiber, Neutral Detergent Fiber, and Nonstarch Polysaccharides in Relation to Animal Nutrition. J. Dairy Sci. 1991, 74, 3583-3597. [CrossRef]

37. Myers, W.D.; Ludden, P.A.; Nayigihugu, V.; Hess, B.W. Technical Note: A Procedure for the Preparation and Quantitative Analysis of Samples for Titanium Dioxide. J. Anim. Sci. 2004, 82, 179-183. [CrossRef]

38. Madrid, J.; Megías, M.D.; Hernández, F. Determination of Short Chain Volatile Fatty Acids in Silages from Artichoke and Orange By-Products by Capillary Gas Chromatography. J. Sci. Food Agric. 1999, 79, 580-584. [CrossRef]

39. Oliveira, L.; Madrid, J.; Ramis, G.; Martínez, S.; Orengo, J.; Villodre, C.; Valera, L.; López, M.J.; Pallarés, F.J.; Quereda, J.J.; et al. Adding Crude Glycerin to Nursery Pig Diet: Effect on Nutrient Digestibility, Metabolic Status, Intestinal Morphology and Intestinal Cytokine Expression. Livest. Sci. 2014, 167, 227-235. [CrossRef]

40. International Organization for Standarization (ISO). Microbiology of Food and Animal Feeding Stuffs-Horizontal Methods for the Detection and Enumeration of Enterobacteriaceae-Part 2: Colony-Count Method; ISO 21528-2; ISO: Geneva, Switzerland, 2004.

41. International Organization for Standarization (ISO). Microbiology of Food and Animal Feeding Stuffs-Horizontal Method for the Enumeration of Coliforms-Colony-Count Technique; ISO 4832; ISO: Geneva, Switzerland, 2006.

42. International Organization for Standarization (ISO). Microbiology of Food and Animal Feeding Stuffs-Horizontal Method for the Enumeration of Mesophilic Lactic Acid Bacteria-Colony-Count Technique at 30 Degrees C; ISO 15214; ISO: Geneva, Switzerland, 1998.

43. Erel, O. A Novel Automated Direct Measurement Method for Total Antioxidant Capacity Using a New Generation, More Stable ABTS Radical Cation. Clin. Biochem. 2004, 37, 277-285. [CrossRef]

44. Erel, O. A New Automated Colorimetric Method for Measuring Total Oxidant Status. Clin. Biochem. 2005, 38, 1103-1111. [CrossRef]

45. Špoljarić, D.; Marenčić, D.; Benković, M.; Špoljarić, B.; Belščak Cvitanović, A.; Mršić, G.; Vlahović, K.; Popović, M.; Srečec, S.; Stolić, I. Effect of Dietary Carob Wholemeal on Blood Parameters in Weaned Pigs. Veterinarski Arhiv 2019, 89, 351-366. [CrossRef]

46. Debski, B. Supplementation of Pigs Diet with Zinc and Copper as Alternative to Conventional Antimicrobials. Polish, J. Vet. Sci. 2016, 19, 917-924. [CrossRef] 
47. Han, Y.; Tang, C.; Li, Y.; Yu, Y.; Zhan, T.; Zhao, Q.; Zhang, J. Effects of Dietary Supplementation with Clostridium butyricum on Growth Performance, Serum Immunity, Intestinal Morphology, and Microbiota as an Antibiotic Alternative in Weaned Piglets. Animals 2020, 10, 2287. [CrossRef] [PubMed]

48. Shang, Q.; Ma, X.; Liu, H.; Liu, S.; Piao, X. Effect of Fibre Sources on Performance, Serum Parameters, Intestinal Morphology, Digestive Enzyme Activities and Microbiota in Weaned Pigs. Arch. Anim. Nutr. 2020, 74, 121-137. [CrossRef] [PubMed]

49. Li, H.; Yin, J.; Tan, B.; Chen, J.; Zhang, H.; Li, Z.; Ma, X. Physiological Function and Application of Dietary Fiber in Pig Nutrition: A Review. Anim. Nutr. 2021, 7, 259-267. [CrossRef] [PubMed]

50. Chen, T.; Chen, D.; Tian, G.; Zheng, P.; Mao, X.; Yu, J.; He, J.; Huang, Z.; Luo, Y.; Luo, J.; et al. Effects of Soluble and Insoluble Dietary Fiber Supplementation on Growth Performance, Nutrient Digestibility, Intestinal Microbe and Barrier Function in Weaning Piglet. Anim. Feed Sci. Tech. 2020, 260, 114335. [CrossRef]

51. Zhang, G.; Zhao, J.; Liu, L.; Zhang, S. Effects of Clostridium butyricum and Corn Bran Supplementation on Growth Performance, Nutrient Digestibility, Faecal Volatile Fatty Acids and Microbiota in Weaned Pigs. J. Appl. Anim. Res. 2020, 48, 313-319. [CrossRef]

52. O'Shea, C.J.; McAlpine, P.; Sweeney, T.; Varley, P.F.; O'Doherty, J.V. Effect of the Interaction of Seaweed Extracts Containing Laminarin and Fucoidan with Zinc Oxide on the Growth Performance, Digestibility and Faecal Characteristics of Growing Piglets. Br. J. Nutr. 2014, 111, 798-807. [CrossRef] [PubMed]

53. Wang, K.; Cao, G.; Zhang, H.; Li, Q.; Yang, C. Effects of Clostridium butyricum and Enterococcus faecalis on Growth Performance, Immune Function, Intestinal Morphology, Volatile Fatty Acids, and Intestinal Flora in a Piglet Model. Food Funct. 2019, 10, 7844-7854. [CrossRef]

54. Li, B.T.; Van Kessel, A.G.; Caine, W.R.; Huang, S.X.; Kirkwood, R.N. Small Intestinal Morphology and Bacterial Populations in Ileal Digesta and Feces of Newly Weaned Pigs Receiving a High Dietary Level of Zinc Oxide. Can. J. Anim. Sci. 2001, 81, 511-516. [CrossRef]

55. Zhu, C.; Lv, H.; Chen, Z.; Wang, L.; Wu, X.; Chen, Z.; Zhang, W.; Liang, R.; Jiang, Z. Dietary Zinc Oxide Modulates Antioxidant Capacity, Small Intestine Development, and Jejunal Gene Expression in Weaned Piglets. Biol. Trace Elem. Res. 2017, 175, 331-338. [CrossRef]

56. Liu, P.; Pieper, R.; Tedin, L.; Martin, L.; Meyer, W.; Rieger, J.; Plendl, J.; Vahjen, W.; Zentek, J. Effect of Dietary Zinc Oxide on Jejunal Morphological and Immunological Characteristics in Weaned Piglets. J. Anim. Sci. 2014, 92, 5009-5018. [CrossRef]

57. Perri, A.M.; O'Sullivan, T.L.; Harding, J.C.S.; Wood, R.D.; Friendship, R.M. Hematology and Biochemistry Reference Intervals for Ontario Commercial Nursing Pigs Close to the Time of Weaning. Can. Vet. J. 2017, 58, 371-376.

58. Ventrella, D.; Dondi, F.; Barone, F.; Serafini, F.; Elmi, A.; Giunti, M.; Romagnoli, N.; Forni, M.; Bacci, M.L. The Biomedical Piglet: Establishing Reference Intervals for Haematology and Clinical Chemistry Parameters of Two Age Groups with and without Iron Supplementation. BMC Vet. Res. 2017, 13, 23. [CrossRef] [PubMed]

59. Caprarulo, V.; Hejna, M.; Giromini, C.; Liu, Y.; Dell'Anno, M.; Sotira, S.; Reggi, S.; Sgoifo-Rossi, C.A.; Callegari, M.L.; Rossi, L. Evaluation of Dietary Administration of Chestnut and Quebracho Tannins on Growth, Serum Metabolites and Fecal Parameters of Weaned Piglets. Animals 2020, 10, 1954. [CrossRef]

60. Klem, T.B.; Bleken, E.; Morberg, H.; Thoresen, S.I.; Framstad, T. Hematologic and Biochemical Reference Intervals for Norwegian Crossbreed Grower Pigs. Vet. Clin. Pathol. 2010, 39, 221-226. [CrossRef]

61. Taranu, I.; Marin, D.E.; Palade, M.; Pistol, G.C.; Chedea, V.S.; Gras, M.A.; Rotar, C. Assessment of the Efficacy of a Grape Seed Waste in Counteracting the Changes Induced by Aflatoxin B1 Contaminated Diet on Performance, Plasma, Liver and Intestinal Tissues of Pigs after Weaning. Toxicon 2019, 162, 24-31. [CrossRef]

62. Silanikove, N.; Landau, S.; Or, D.; Kababya, D.; Bruckental, I.; Nitsan, Z. Analytical Approach and Effects of Condensed Tannins in Carob Pods (Ceratonia siliqua) on Feed Intake, Digestive and Metabolic Responses of Kids. Livest. Sci. 2006, 99, 29-38. [CrossRef]

63. Abia, R.; Fry, S.C. Degradation and Metabolism of 14C-Labelled Proanthocyanidins from Carob (Ceratonia siliqua) Pods in the Gastrointestinal Tract of the Rat. J. Sci. Food Agric. 2001, 81, 1156-1165. [CrossRef]

64. López-Andrés, P.; Luciano, G.; Vasta, V.; Gibson, T.M.; Biondi, L.; Priolo, A.; Mueller-Harvey, I. Dietary Quebracho Tannins Are Not Absorbed, but Increase the Antioxidant Capacity of Liver and Plasma in Sheep. Br. J. Nutr. 2013, 110, 632-639. [CrossRef] [PubMed]

65. Liu, H.; Tan, B.; Huang, B.; Li, J.; Wang, J.; Liao, P.; Guan, G.; Ji, P.; Yin, Y. Involvement of Calcium-Sensing Receptor Activation in the Alleviation of Intestinal Inflammation in a Piglet Model by Dietary Aromatic Amino Acid Supplementation. Br. J. Nutr. 2018, 120, 1321-1331. [CrossRef] [PubMed]

66. Hu, C.; Song, J.; Li, Y.; Luan, Z.; Zhu, K. Diosmectite-Zinc Oxide Composite Improves Intestinal Barrier Function, Modulates Expression of pro-Inflammatory Cytokines and Tight Junction Protein in Early Weaned Pigs. Br. J. Nutr. 2013, 110, 681-688. [CrossRef] [PubMed]

67. Kloubert, V.; Blaabjerg, K.; Dalgaard, T.S.; Poulsen, H.D.; Rink, L.; Wessels, I. Influence of Zinc Supplementation on Immune Parameters in Weaned Pigs. J. Trace Elem. Med. Biol. 2018, 49, 231-240. [CrossRef]

68. Li, H.-H.; Li, Y.-P.; Zhu, Q.; Qiao, J.-Y.; Wang, W.-J. Dietary Supplementation with Clostridium butyricum Helps to Improve the Intestinal Barrier Function of Weaned Piglets Challenged with Enterotoxigenic Escherichia coli K88. J. Appl. Microbiol. 2018, 125, 964-975. [CrossRef] 
69. Qiao, J.; Li, H.; Wang, Z.; Wang, W. Effects of Lactobacillus acidophilus Dietary Supplementation on the Performance, Intestinal Barrier Function, Rectal Microflora and Serum Immune Function in Weaned Piglets Challenged with Escherichia coli Lipopolysaccharide. Antonie van Leeuwenhoek 2015, 107, 883-891. [CrossRef]

70. Guerra-Ordaz, A.A.; González-Ortiz, G.; La Ragione, R.M.; Woodward, M.J.; Collins, J.W.; Pérez, J.F.; Martín-Orúe, S.M. Lactulose and Lactobacillus plantarum, a Potential Complementary Synbiotic to Control Postweaning Colibacillosis in Piglets. Appl. Environ. Microbiol. 2014, 80, 4879-4886. [CrossRef]

71. Aboura, I.; Nani, A.; Belarbi, M.; Murtaza, B.; Fluckiger, A.; Dumont, A.; Benammar, C.; Tounsi, M.S.; Ghiringhelli, F.; Rialland, M.; et al. Protective Effects of Polyphenol-Rich Infusions from Carob (Ceratonia siliqua) Leaves and Cladodes of Opuntia ficus-indica against Inflammation Associated with Diet-Induced Obesity and DSS-Induced Colitis in Swiss Mice. Biomed. Pharmacother. 2017, 96, 1022-1035. [CrossRef] [PubMed]

72. Arribas, C.; Pereira, E.; Barros, L.; Alves, M.J.; Calhelha, R.C.; Guillamón, E.; Pedrosa, M.M.; Ferreira, I.C.F.R. Healthy Novel Gluten-Free Formulations Based on Beans, Carob Fruit and Rice: Extrusion Effect on Organic Acids, Tocopherols, Phenolic Compounds and Bioactivity. Food Chem. 2019, 292, 304-313. [CrossRef] [PubMed] 